\title{
SISTEM INVENTORY MANAGEMENT UNTUK MENINGKATKAN VOLUME PENJUALAN DI TOKO HOKKY KRIAN
}

\author{
Fitriyani Gondowijoyo ${ }^{1)}$, Michael Ricky Sondak ${ }^{2)}$ \\ Fakultas Manajemen \& Bisnis Universitas Ciputra Surabaya \\ Universitas Ciputra Surabaya \\ email $^{1)}$ : fitriyani@yahoo.com \\ email $^{2)}$ : michael@ciputra.ac.id
}

\begin{abstract}
This research aim for understanding the influence of inventory management system in increasing sales volume at Hokky Krian Store. The presence of inventory management system helping Hokky Krian Store increasing the sales volume. The population used in this research was the people working in inventory at Hokky Krian Store. The sample that being used in this research were the whole population because the population count is not much. Sample pulling technique used was non-probability sampling. This research using qualitative study case method. Data sources came from two sources, which is primary data including interview and observation, and secondary data from Hokky Krian Store financial report and literature from journals, books, and documents. Collecting method via interview with three research subjects, which is Hokky Store's owner, Hokky Store's supervisor, and an inventory management's expert. Observation and documents analysis at Hokky Krian Store also used for collecting data in this research. Analysis technique used was Triangulation technique which is data validity checking technique that using outside data for checking and comparing the data. The result of this research concludes that good inventory management system will increase Hokky Krian Store sales volume. Therefore inventory should be done on a regular basis and the cost should be accounted whether inventory cost and production cost, controlling stock for bestseller item.

Keywords: Inventory Management System, Sales Volume
\end{abstract}

\begin{abstract}
Abstrak
Penelitian ini bertujuan untuk mengetahui bagaimanakah sistem inventory management untuk meningkatkan volume penjualan di Toko Hokky Krian.Adanya sistem inventory management ini membantu Toko Hokky Krian dalam meningkatkan volume penjualannya. Populasi yang digunakan dalam penelitian ini adalah hanya orang yang berada pada bagian inventory di Toko Hokky Krian. Sampel yang diambil dalam penelitian ini adalah seluruh populasi ada karena jumlah populasi relatif kecil.Teknik penarikan sampel yang digunakan adalah non-probability sampling.Penelitian ini menggunakan metode kualitatif studi kasus. Sumber data dalam penelitian ini terdapat dua sumber data, yaitu data primer meliputi wawancara dan observasi serta data sekunder yaitu, dari analisis dokumen dari laporan keuangan Toko Hokky Krian serta studi literatur dari jurnal, buku, dan dokumen. Metode pengumpulan yang digunakan adalah wawancara yang dilakukan dengan melibatkan tiga orang subyek penelitian, yaitu pemilik Toko Hokky Krian, supervisor Toko Hokky Krian, dan expert pada bidang inventory management. Selain itu, observasi pada Tokky Hokky Krian dan analisis dokumen Toko Hokky Krian juga merupakan metode pengumpulan data yang digunakan pada penelitian ini. Teknik analisis yang digunakan adalah teknik triangulasi yang merupakan teknik pemeriksaan keabsahan data yang memanfaatkan sesuatu yang lain di luar data itu untuk pengecekan atau sebagai pembanding terhadap data itu. Hasil dari penelitian ini ialah sistem inventory management yang baik dapat meningkatkan volume penjualan di Toko
\end{abstract}


Hokky Krian. Maka dari itu, inventory harus dilakukan secara teratur dan biaya-biaya yang dikeluarkan harus diperhitungkan baik biaya penyimpanan maupun biaya produksi serta tidak usah menambahkan stock pada item yang tidak laku dan menambah jumlah stock pada item yang laku.

Kata Kunci: Sistem Inventory Management, Volume Penjualan

\section{PENDAHULUAN}

Dewasa ini, perkembangan industri bahan makanan mengalami perkembangan yang sangat pesat sehingga terjadi persaingan yang tinggi. Berdasarkan data industri roti dan kue diperkirakan akan terus meroket hingga $15 \%$ pada 2015 (Actual.co, 2014). Hal ini didukung oleh pernyataan Chris Hardijaya selaku Ketua Komite Tetap Makanan Tradisional Kamar Dagang dan Industri (Kadin) Indonesia. Dalam suatu perusahaan dibutuhkan hal yang penting yaitu pengaturan pada persediaan barang. Inventory merupakan hal yang sangat mendasar dan sangatlah berpengaruh penting dalam mempermudah menembus persaingan yang ketat pada saat sekarang ini. Menurut Stephyna (2011:1) mengatakan bahwa :

Persediaan merupakan salah satu masalah fenomenal yang bersifat fundamental dalam perusahaan. Persediaan dapat diartikan sebagai stock barang yang akan dijual atau digunakan pada periode waktu tertentu. Tanpa adanya persediaan, perusahaan akan dihadapkan pada sebuah risiko, tidak dapat memenuhi keinginan para pelanggannya.

Menurut Putri (2014:21), Salah satu unsur yang paling penting dalam perusahaan dagang adalah persediaan. Persediaan merupakan barang dagangan yang dibeli kemudian disimpan untuk selanjutnya dijual kembali dalam operasi. Perusahaan senantiasa memberi perhatian yang besar dalam persediaan. Sedangkan menurut Heizer dan Reinder (2011:500) Inventory is the one of the most expensive assets of many companies, representing as much as $50 \%$ of total invested capital. Inventory adalah salah satu aset termahal dari banyak perusahaan, mewakili sebanyak 50\% dari keseluruhan modal yang diinvestasikan.

Inventory atau persediaan barang merupakan modal dari suatu 
perusahaan maka dibutuhkan inventory control atau pengendalian persediaan barang. Menurut Tamodia (2013:1), Salah satu fungsi manajerial yang sangat penting dalam operasional suatu perusahaan adalah pengendalian persediaan (inventory control), karena kebijakan persediaan secara fisik akan berkaitan dengan investasi dalam aktiva lancar di satu sisi dan pelayanan kepada pelanggan di sisi lain. Suatu penelitian menyatakan bahwa Proper management and control of inventory not only solve the problem of liquidity but also increase profitability. Inventory establishes a link between production and sales. Manajemen yang tepat dan pengendalian persediaan tidak hanya memecahkan masalah likuiditas tetapi juga meningkatkan profitabilitas. Persediaan menetapkan hubungan antara produksi dan penjualan (Panigrahi, 2013:108) oleh karena itu, dibutuhkan manajemen dan pengendalian persediaan yang baik untuk meningkatkan penjualan.

Toko Hokky Krian merupakan toko bahan kue yang berdiri sejak tahun 1999. Berdasarkan hasil wawancara dengan supervisor Toko Hokky Krian pada bulan Februari 2015 maka dapat diketahui masalah yang terjadi di Toko Hokky Krian. Toko bahan kue yang berasal dari toko yang sederhana dengan jenis barang yang jumlah yang kurang dari 100 jenis dengan pelanggan yang minim kemudian sekarang ini berkembang menjadi toko bahan kue yang cukup besar di Krian. Dengan bertambah besarnya toko bahan kue maka semakin banyak permintaan dari pelanggan sehingga jenis barang yang dijual semakin bertambah hingga tahun ini total jenis barang sekitar 3000 jenis. Sedangkan dari 3000 jenis bahan kue tersebut memiliki cara penyimpanan yang berbeda-beda karena setiap makanan memiliki karakteristik yang berbedabeda. Sedangkan di sisi lain, permintaan pasar tinggi di event tertentu yang dimana juga inventory harus dapat dikelola dengan cermat dan teliti berkaitan dengan tanggal kadaluarsa bahan-bahan kue tersebut. Sedangkan banyaknya jumlah jenis barang di Toko Hokky Krian maka diperlukan ketelitian untuk mengetahui tinggi atau rendahnya permintaan pelanggan terhadap 
setiap jenisnya sehingga dapat melakukan inventory dengan baik tanpa harus ada barang yang terbuang karena tidak adanya permintaan. Karena itu di Toko Hokky Krian ini diperlukan pengendalian barang secara tepat karena akan sangat berpengaruh pada volume penjualan. Berdasarkan latar belakang masalah dan pokok pemikiran di atas, maka peneliti tertarik untuk meneliti lebih spesifik mengenai sistem inventory management untuk meningkatkan volume penjualan di Toko Hokky Krian.

\section{TINJAUAN KEPUSTAKAAN}

Menurut Affandi et al (2012:39) inventori merupakan investasi yang paling besar pada sebagian besar perusahaan industri. Persediaan diperlukan untuk dapat melakukan proses produksi, penjualan persediaan bahan mentah dan barang dalam proses diperlukan untuk menjamin kelancaran proses produksi, sedangkan bahan jadi harus tetap tersedia agar memungkinkan perusahaan memenuhi permintaan yang terjadi. Adapun pengertian inventory menurut Jacobs and Chase (2013:357) Inventory is the stock of any item or resource used in an organization. Persediaan merupakan kumpulan dari berbagai jenis barang atau bahan yang akan digunakan oleh suatu perusahaan.

Manajer operasi membuat sistem-sistem untuk mengelola persediaan. Pada bagian ini, dua unsur yang dibahas dari sistem tersebut secara singkat: bagaimana barang-barang persediaan dapat diklasifikasikan (disebut analisis ABC) dan (2) seberapa akurat catatan persediaan dapat dijaga. Kemudian, akan mengamati kontrol persediaan dalam sektor layanan (Heizer dan Render, 2010:84-89).

1. Analisis $\mathrm{ABC}$ membagi persediaan yang ada menjadi tiga klasifikasi dengan basis volume dolar tahunan. Analisis $\mathrm{ABC}$ adalah sebuah aplikasi persediaan dari prinsip Pareto. Prinsip Pareto menyatakan sedikit hal yang kritis dan banyak yang sepele. Gagasannya adalah untuk membuat kebijakan-kebijakan persediaan yang memfokuskan persediaan pada bagian-bagian persediaan kritis yang sedikit 
dan tidak pada banyak yang sepele. Tidaklah realistis jika memantau barang-barang yang tidak mahal dengan intensitas yang sama dengan barangbarang yang sangat mahal. Untuk menentukan volume dolar tahunan dari analisis ABC, caranya dengan mengukur permintaan tahunan dari setiap barang persediaan dikalikan biaya per unitnya. Barang-barang kelas A adalah barang-barang yang volume tahunannya tinggi. Walaupun barang-barang ini mungkin hanya mempresentasikan $15 \%$ dari barang-barang persediaan total, tetapi barang-barang tersebut merepresentasikan $70 \%$ sampai $\quad 80 \%$ dari penggunaan uang secara keseluruhan. Barang-barang Kelas B adalah barang persediaan dengan volume dolar tahunan yang sedang. Barang-barang ini mungkin merepresentasikan sekitar 30\% dari barang-barang persediaan dan $15 \%$ sampai $25 \%$ dari nilai total. Barang-barang dengan volume tahunan yang kecil adalah Kelas $\mathrm{C}$ yang mungkin hanya merepresentasikan 5\% dari volume dolar tahunan, tetapi mewakili sekitar 55\% barang-barang persediaan total.

2. Akurasi catatan adalah sebuah unsur kritis dalam sistem produksi dan persediaan. Akurasi catatan mengizinkan organisasi untuk fokus pada barang-barang yang diperlukan, alih-alih menetapkan untuk yakin bahwa "beberapa dari semuanya" berada dalam persediaan. Hanya ketika sebuah organisasi dapat menentukan secara akurat apa yang dimilikinya sekarang, organisasi tersebut dapat mengambil keputusan yang tepat mengenai pemesanan, penjadwalan, dan pengiriman.

3. Kontrol Persediaan Pelayanan memiliki teknik- teknik yang dapat digunakan yaitu:

a. Pemilihan, pelatihan, dan pendisiplinan pegawai yang baik

b. Kontrol yang ketat dari pengiriman yang datang 
c. Kontrol yang efektif atas semua barang yang meninggalkan fasilitas.

Economic Order Quantity (EOQ):

\section{The Traditional Model}

Menurut Hansen dan Mowen (2012: 318-325) Economic Order Quantity (EOQ): Model inventory tradisional sebuah perusahaan yang memutuskan untuk menyimpan inventory, harus mempertimbangkan dua pertanyaan penting:

1. Berapa banyak yang seharusnya dipesan?

2. Kapan seharusnya pesanan tersebut tiba?

Kemudian dari alasan menggunakan model inventory tradisional. Alasan yang diteliti adalah:

1. Memperhitungkan biaya pemesanan atau biaya mesin dan biaya penyimpanannya.

2. Memenuhi permintaan pelanggan, contohnya tepat waktu saat pengiriman barang.

3. Untuk menghindari penutupan fasilitas produksi karena kerusakan mesin, bahan baku yang rusak, bahan baku yang tidak tersedia, dan bahan baku yang terlambat dikirim.

4. Melindungi dari proses produksi yang tidak dapat diandalkan.

5. Mendapatkan keuntungan dari potongan harga.

6. Mencegah kenaikan harga di masa mendatang.

Biaya Inventory Menurut Hansen dan Mowen (2013: 1030), biaya-biaya inventory untuk

Just-in-Time Inventory management atau traditional ada empat, yaitu

1. Ordering costs adalah biaya untuk menempatkan dan menerima pesanan.

2. Setup costs adalah biaya untuk mempersiapkan alat dan fasilitas sehingga dapat digunakan untuk menghasilkan sebuah bagian atau komponen dari produk.

3. Carrying costs adalah biaya karena melakukan penyimpanan persediaan barang.

4. Stock-out costs adalah biaya yang diakibatkan karena tidak memiliki produk saat terdapat permintaan dari pelanggan. 
Kebijakan Pemesanan Inventory

Menurut Stevenson (2012:

566) Kebjiakan pemesanan inventory menunjukan dua dasar persoalan dari inventory manajemen, antara lain

1. Cycle Stock, jumlah dari inventory yang dibutuhkan untuk memenuhi permintaan.

2. Safety Stock, tambahan inventory yang dibawa untuk mengurangi kemungkinan kehabisan persediaan berdasarkan permintaan dan/atau disebabkan oleh waktu yang berubah-ubah.

\section{Volume Penjualan}

Menurut

Rachmawati

(2011:148) Volume penjualan dapat dijabarkan sebagai umpan balik dari kegiatan pemasaran yang dilaksanakan oleh perusahaan. Adapun pengertian volume penjualan menurut Mulyadi (dalam Firdaus, 2011:147) Volume penjualan merupakan ukuran yang menunjukan banyaknya atau besarnya jumlah barang dan jasa yang terjual. Sedangkan menurut business dictionary (businessdictionary.com), sales volume is the quantity or number of goods or services sold in the normal operations of a company in a specified period. Volume penjualan adalah kuantitas atau jumlah dari barang atau jasa yang terjual dalam suatu perusahaan dalam waktu tertentu. 


\section{KERANGKA KONSEPTUAL}

\section{Pendahuluan}

Dewasa ini, perkembangan industri bahan makanan mengalami perkembangan yang sangat pesat sehingga terjadi persaingan yang tinggi. Toko Hokky Krian merupakan toko bahan kue yang memiliki 3000 jenis barang. Oleh karena itu, dibutuhkan analisis sistem inventory management dalam upaya meningkatkan penjualan.

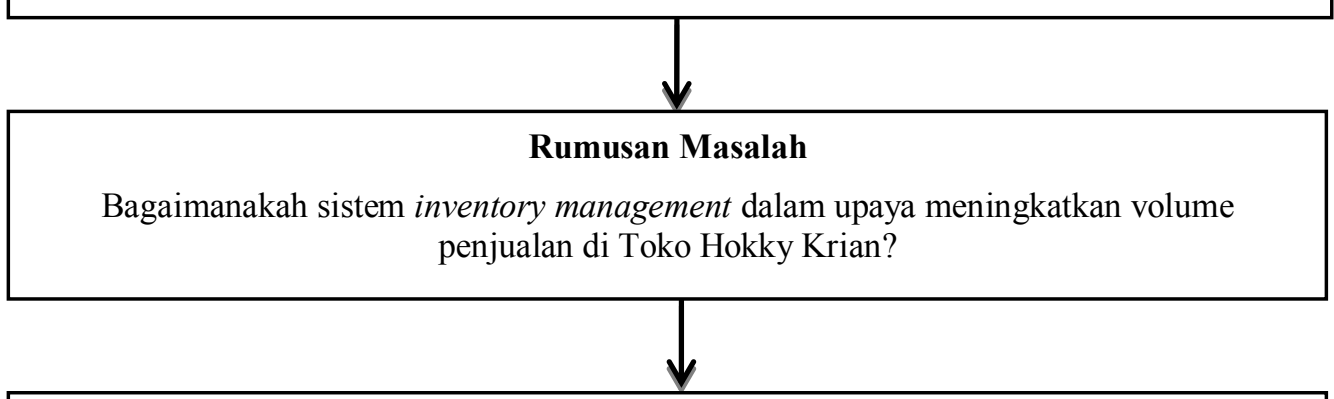

\section{Tinjauan Kepustakaan}

1. Klasifikasi model inventory management menurut Hansen dan Mowen (2013:318-325) yaitu, Economic Order Quantity (EOQ): Model Inventory Tradisional Sebuah perusahaan yang memutuskan untuk menyimpan inventory, harus mempertimbangkan dua pertanyaan penting: (a) Berapa banyak yang seharusnya dipesan? (b) Kapan seharusnya pesanan tersebut tiba?

2. Biaya Inventory (Hansen dan Mowen, 2013:1030):
a. Ordering costs.
b. Setup costs.
c. Carrying costs.
d. Stock-out costs.

3. Volume Penjualan menurut Mulyadi (dalam Firdaus, 2011:147).

Volume penjualan merupakan ukuran yang menunjukan banyaknya atau besarnya jumlah barang dan jasa yang terjual.

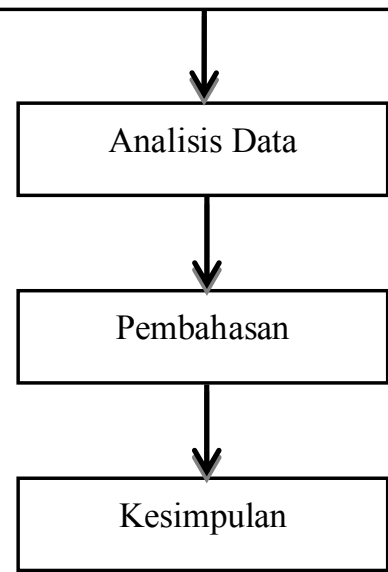




\section{METODE PENELITIAN}

Dalam penelitian ini, peneliti menggunakan metode penelitian kualitatif studi kasus. Studi kasus adalah strategi yang digunakan ketika terdapat pertanyaanpertanyaan bagaimana ataupun mengapa, ketika peneliti memiliki sedikit kekuasaan atas peristiwaperistiwa yang terjadi, serta ketika fokus peneliti berada pada sebuah fenomena yang terjadi dalam beberapa konteks kehidupan nyata. Penggunaan metode kualitatif pada penelitian ini disebabkan karena sedikitnya jumlah populasi penelitian dan diharapkan dengan penggunaan metode kualitatif deskriptif dapat memperoleh hasil yang lebih kompleks. Penelitian ini digunakan untuk mendapatkan informasi mengenai sistem inventory management untuk meningkatkan volume penjualan.

Populasi dari penelitian ini adalah hanya orang yang berada pada bagian inventory di Toko Hokky Krian serta pemilik Toko Hokky Krian. Pemilik juga termasuk dalam populasi penelitian karena pemilik juga memahami dan mengetahui tentang cara kerja inventory di Toko Hokky Krian. Total jumlah populasi penelitian adalah dua orang. Sampel yang dipilih berfungsi untuk mendapatkan informasi yang maksimum. Sampel yang akan digunakan dalam penelitian berjumlah dua informan yang ialah pemilik dan supervisor Toko Hokky Krian. Teknik penarikan sampel yang digunakan dalam penelitian ini adalah non-probability sampling. Non-probability sampling merupakan metode sampling yang setiap individu atau unit dari populasi tidak memiliki kemungkinan yang sama untuk terpilih (Herdiansyah, 2010: 106).

Ada dua macam sumber data yang digunakan yaitu, data primer dan data sekunder. Data primer adalah data yang diperoleh dari sumber aslinya, yaitu Toko Hokky Krian. Dalam penelitian ini, data primer merupakan hasil wawancara dengan pemilik dan supervisor Toko Hokky Krian serta observasi yang dilakukan pada Toko Hokky Krian. Data sekunder didapatkan dari sumber-sumber dan data yang mendukung, seperti laporan keuangan Toko Hokky Krian dan dokumen-dokumen Toko Hokky Krian.Selain itu, juga menggunakan studi literatur dari jurnal, buku, dan 
dokumen.

Metode pengumpulan data yang digunakan adalah wawancara, observasi, dan analisis dokumen. Teknik analisis data yang digunakan dalam penelitian ini adalah teknik triangulasi. Menurut Moleong (2010: 330), triangulasi adalah teknik pemeriksaan keabsahan data yang memanfaatkan sesuatu yang lain di luar data itu untuk keperluan pengecekan atau sebagai pembanding terhadap data itu. Jenis triangulasi yang digunakan dalam penelitian ini adalah triangulasi dengan metode. Pada triangulasi dengan metode, Patton dalam Moleong (2010: 331) menjelaskan terdapat dua strategi, yaitu: (1) pengecekan derajat kepercayaan penemuan hasil penelitian beberapa teknik pengumpulan data dan (2) pengecekan derajat kepercayaan beberapa sumber data dengan metode yang sama. Selain menggunakan teknik triangulasi dalam penelitian kualitatif ini, peneliti melakukan tiga langkah persiapan, yaitu memilih narasumber untuk diwawancarai, membuat catatan etnografis, dan mengumpulkan data-data penjualan.
Setelah peneliti melakukan persiapan tersebut maka peneliti siap menjawab pertanyaan-pertanyaan yang telah dirumuskan dan kemudian mengumpulkan data yang lebih banyak.

\section{PEMBAHASAN}

\section{Deskripsi Data Informan}

Informan A adalah pemilik dari Toko Hokky Krian. Informan A ini tidak memiliki pendidikan yang tinggi. Pendidikan terakhir yang ditempuhnya ialah Sekolah Dasar (SD), dengan pendidikan yang dipunyainya dan keberanian untuk bekerja akhirnya Informan A dapat menjalankan bisnisnya hingga berkembang seperti sekarang ini.

Informan B adalah supervisor dari Toko Hokky Krian. Pendidikan terakhir yang diambilnya adalah Sekolah Menengah Atas (SMA) yang berada di Surabaya. Informan B ini mempunyai pengalaman bekerja di Game Republic dengan bidang yang sama selama empat tahun. Informan B bergabung dengan Toko Hokky Krian sejak Januari 2012. Informan B yang membantu membuat sistem inventory bagi Toko Hokky Krian. 
Informan $\mathbf{C}$ adalah seorang pemilik restoran yang digunakan untuk mendapatkan masukan dan sudut pandang seorang pakar, yaitu owner dari sebuah restoran di Jakarta serta merupakan seorang private Chef.

\section{Analisis dan Pembahasan}

\section{Economic Order Quantity} (EOQ): Model Inventory Tradisional

Berdasarkan hasil wawancara, Informan A dan B mengatakan Toko Hokky Krian menggunakan sistem inventory sejak pertengahan tahun 2012 . Menurut Informan A sistem inventory adalah sistem yang mengatur dan mengontrol barang-barang yang ada di toko sedangkan menurut Informan $\mathrm{B}$, sistem inventory adalah sistem untuk me-manage stock barang di toko. Menurut Informan $\mathrm{C}$, sistem inventory adalah in and out cashflow dari suatu perusahaan dimana jika ada kondisi barang yang rusak saat penyimpanan maka harus diperhitungkan sebagai biaya dalam penyimpanan, jika tidak diperhitungkan maka akan mengalami kerugian dan biasanya harganya ditambah $10 \%$.

Informan A dan B mengatakan bahwa sistem inventory sangat penting bagi Toko Hokky Krian karena jika tidak ada sistem inventory maka akan sulit untuk dapat mengetahui stock barang. Menurut Informan C, sistem inventory penting bagi suatu perusahaan. Sistem inventory yang menggunakan komputerisasi maka untuk error-nya hampir nol, yaitu $0,2 \%$ sampai dengan $0,3 \%$ tetapi jika menggunakan tenaga manusia maka bisa terjadi human error diatas $10 \%$ sekitar 20\% sampai dengan $30 \%$. Informan A mengatakan pemesanan barang untuk inventory disesuaikan dengan data penjualan sedangkan Informan B mengatakan pemesanan barang untuk inventory disesuaikan dengan data penjualan dan estimasi penjualan yang begantung dari bulan-bulan yang ramai atau sepi. Menurut Stevenson (2012: 566), kebjiakan pemesanan inventory 


$$
\begin{aligned}
& \text { menunjukkan dua dasar } \\
& \text { persoalan dari inventory } \\
& \text { manajemen antara lain: } \\
& \text { a. Cycle Stock, jumlah } \\
& \text { dari inventory yang } \\
& \text { dibutuhkan untuk } \\
& \text { memenuhi permintaan. } \\
& \text { b. Safety Stock, tambahan } \\
& \text { inventory yang dibawa } \\
& \text { untuk mengurangi } \\
& \text { kemungkinan } \\
& \text { kehabisan persediaan } \\
& \text { berdasarkan permintaan } \\
& \text { dan/atau disebabkan } \\
& \text { oleh waktu yang } \\
& \text { berubah-ubah. }
\end{aligned}
$$

Informan A dan B mengatakan lama pengiriman barang sekitar satu sampai dua hari dan pesanan barang tidak selalu datang sesuai dengan waktunya.Informan A dan B mengatakan bahwa pengiriman barang tidak dapat selalu tiba tepat waktunya. Menurut Jacobs and Chase (2013:357-358), salah satu alasan semua perusahaan menjaga pasokan persediaan adalah untuk mempertahankan suatu kemandirian operasi. Informan A menyampaikan bahwa adanya kendala sopir yang absen, kerusakan mobil, dan barang yang dikirim dari pabrik belum siap sedangkan informan

menyampaikan bahwa faktor-faktor yang mempengaruhi keterlamabatan barang adalah karena stock barang dari pabrik tidak tersedia, stock barang kosong, dan lokasi dari Toko Hokky Krian yang berada di luar kota sehingga harus menunggu jadwal pengiriman dari pabrik. Selvia (2014:33) mengatakan dengan sistem Economic Order Quantity (EOQ) membantu perusahaan mengetahui jumlah persediaan bahan jadi minimum per periode. Perusahaan dapat mengetahui waktu siklus pemesanan ulang dan frekuensi dalam satu bulan sehingga meminimalkan opportunity cost yang timbul akibat pengiriman tidak tepat waktu kepada pelanggan. Perusahaan juga mengetahui persediaan optimal yang disesuaikan dengan asumsi kenaikan permintaan sehingga kecil kemungkinan terjadi kelebihan stock yang berdampak pada kerusakan produk.

Informan A dan B mengatakan tidak adanya biaya pemesanan dan biaya mesin, yang ada hanya biaya penyimpanan karena untuk menyimpan barang dibutuhkan gudang dan tenaga pegawai. 
Informan $\mathrm{C}$ mengatakan untuk biaya mesin yang dikeluarkan adalah biaya produk mesin dan programnya, untuk biaya pemesanan dibutuhkan biaya untuk membeli produk dari supplier sedangkan untuk biaya penyimpanan maka dibutuhkan rak, program untuk mengatur data. Informan A dan B mengatakan bahwa dengan sistem inventory ini dapat memenuhi permintaan pelanggan dengan tepat waktu dan barang sampai kepada pelanggan dengan baik yang dilakukan dengan cara selalu mengontrol stock barang setiap satu minggu satu kali. Menurut Jacobs and Chase (2013:357-358), salah satu fungsi inventory adalah fleksibilitas dalam jadwal produksi. Di Toko Hokky Krian ada barang yang diproduksi sendiri maka dari itu jika terjadi kerusakan mesin maka yang dilakukan informan $\mathrm{A}$ adalah menghubungi teknisi mesin secepatnya sedangkan informan B mengatakan bahwa mesin yang digunakan untuk produksi bukanlah mesin yang besar jadi dalam kurun waktu yang cepat dapat diselesaikan. Jika terjadi bahan baku rusak maka informan A secepatnya memesan bahan baku baru lagi sedangkan informan B melihat dari seberapa lama bahan baku itu tidak ada, jika dalam waktu yang pendek maka tidak perlu khawatir karena stock barang masih ada tetapi jika dalam waktu yang lama bahan baku masih tidak ada maka harus mencari bahan baku pengganti. Apabila bahan baku tidak tersedia maka informan A mencari bahan baku pengganti agar tetap bisa melanjutkan produksi sedangkan informan B apabila ketersediaan dalam waktu dekat jika masih ada stock barang maka informan $\mathrm{B}$ akan menunggu tetapi kalau teralalu lama maka akan diusahakan utuk mencari produk pengganti yang sejenis. Kalau terjadi masalah dalam keterlambatan pengiriman bahan baku maka informan A akan secepatnya menghubungi pihak pabrik yang bersangkutan sehubungan dengan pengiriman barang agar dapat cepat dikirim sedangkan informan $\mathrm{B}$ dapat mengatasi permasalahan ini karena informan B selalu mempunyai minimal stock yang cukup karena pertimbangan lokasi Toko Hokky Krian berada di luar kota. Menurut Jacobs and Chase (2013:357-358), salah satu fungsi inventory adalah 
menjamin ketepatan waktu pemasok dalam pengiriman bahan baku. Informan A mengatakan ada kendala lain yang mengganggu jalannya produksi yaitu jika secara tiba-tiba mati lampu atau pegawai yang tidak masuk tetapi informan A tidak khawatir karena dengan sistem inventory ini masih ada stock barang yang bisa dijual. Informan A dan B mengatakan dengan sistem inventory dapat dilindungi dari proses produksi yang tidak dapat selesai pada waktu yang ditetapkan karena sudah ada minimal stock barang yang ada di Toko Hokky Krian. Menurut Mangan et al (2012:207) inventory adalah:

Persediaan merupakan salah satu arus paling penting dalam rantai pasokan, dan bagaimana hal itu dapat dikelola akan berdampak signifikan pada keberhasilan perusahaan. persediaan dapat ditemukan dibeberapa titik dalam rantai pasokan, dan bahwa dengan mengukur perputaran persediaan... dapat mengukur secara pasti seberapa efektif suatu organisasi mengelola persediaan. Dalam banyak kasus persediaan digunakan untuk penyangga terhadap ketidakpastian, dan selanjutnya dapat menyelesaikan masalah.
Adanya sistem inventory dalam suatu perusahaan maka akan membantu suatu perusahaan dari suatu ketidapastian produksi serta dapat membantu Toko Hokky Krian dalam mengalami masalah seperti masalah pada mesin, kerusakan bahan baku, ketidaktersediaan bahan baku, dan keterlambatan pengiriman. Sedangakan informan C mengatakan bahwa proses produksi yang tidak dapat diandalkan bukan masalah sistem inventory dari suatu perusahaan melainkan rata-rata yang menjadi masalah adalah sumber daya manusia yang mengerjakan proses produksi.

Dalam sistem inventory ini, informan A dan B mendapatkan keuntungan potongan harga yang dikarenakan dengan pengambilan jumlah tertentu Toko Hokky Krian mendapatkan potongan harga. Selain itu, informan A mengatakan biasanya mengikuti program yang diadakan oleh pabrik-pabrik. Program yang diadakan oleh pabrik seperti program pengambilan jumlah berbeda semakin besar maka harganya akan semakin murah atau jika tidak pengambilan 25 kardus mendapatkan bonus satu kardus. Informan C 
mengatakan bahwa dengan sistem inventory yang baik maka bisa mendapatkan potongan harga dengan analogi dari informan $\mathrm{C}$ sebagai berikut, apabila membeli $5 \mathrm{~kg}$ daging kemudian dipakai $4 \mathrm{~kg}$ sisa $1 \mathrm{~kg}$ yang kemudian yang $1 \mathrm{~kg}$ ini minggu berikutnya akan mengalami penurunan harga maka dari itu dapat dilakukan overlapping inventory untuk dapat dijadikan sebagai ekstra atau dapat dimasukkan pada inventory setelahnya. Menurut Jacobs and Chase (2013:357-358), salah satu fungsi dari inventory adalah mengambil keuntungan dari pembelian ukuran pemesanan sehingga lebih ekonomis. Pada penelitian terdahulu yang dilakukan oleh Danudibrata (2014:45), dengan menggunakan metode Economic Order Quantity (EOQ), perusahaan dapat mengendalikan persediaan dengan efektif dan dapat menerima semua pesanan yang ada. Sebagai tambahan metode Economic Order Quantity (EOQ) dapat menghemat totalcost sebesar $45,36 \%$ dan mengetahui persediaan. Perusahaan juga mengetahui titik pemesanan ulang dan frekuensi pembelian persediaan.
Informan B mengatakan kenaikan harga pada masa mendatang tidak dapat dicegah dengan adanya sistem inventory karena kenaikan harga ditentukan oleh mekanisme pasar bukan sistem inventory jadi apabila terjadi kenaikan harga maka informan $\mathrm{B}$ akan menaikkan harga. Demikian juga informan A mengatakan sistem inventory tidak bisa mencegah kenaikan harga pada masa mendatang karena informan A harus mengikuti harga baru jika tidak akan mengalami kerugian. Informan C mengatakan bahwa dengan sistem inventory tidak mempengaruhi secara signifikan untuk dapat mencegah kenaikan harga dimasa mendatang. Informan A dan B mengatakan bahwa kenaikan harga tidak bisa dicegah tetapi jika ada pemberian harga ekstra dari pabrik maka informan A dan B dapat menahan lonjakan harga tetapi hanya untuk sesaat saja. Menurut Hansen dan Mowen (2012:318-325), salah satu alasan untuk menggunakan model inventory tradisional adalah untuk mencegah kenaikan harga di masa mendatang. 
Biaya Inventory

Informan A dan B mengatakan tidak ada biaya yang dikeluarkan untuk menempatkan pesanan karena biasanya para sales yang datang ke Toko Hokky Krian untuk menawarkan barang. Tetapi untuk biaya penyimpanan informan $\mathrm{A}$ dan B mengatakan bahwa dibutuhkan biaya gudang dan pegawai. Menurut Hansen dan Mowen (2013:1030), Ordering costs adalah biaya untuk menempatkan dan menerima pesanan. Informan $\mathrm{C}$ mengatakan untuk membeli pesanan harus diperhatikan bahwa barang-barang tertentu seperti kaleng-kalengan sebaiknya pembelian dilakukan dengan konsinyasi sehingga jika ada kaleng yang rusak dapat ditukar kembali tanpa mengalami kerugian. Sebaliknya jika produk yang cepat rusak seperti krim usahakan dapat melakukan konsinyasi dengan supplier apabila barang tersebut tidak terjual dan mengalami kerusakan maka dari pihak toko akan membayar sesuai dengan harga konsinyasi. Penyimpanan pesanan yang dibutuhkan adalah lemari es dan gudang. Informan $\mathrm{C}$ mengatakan untuk penyimpanan di gudang biasanya memiliki masalah dengan adanya tikus, serangga, dan semut. Saat mengatasi masalah tersebut akan butuh biaya yang dikeluarkan.

Dalam menjalankan produksi maka dibutuhkan alat dan fasilitas untuk menghasilkan produk, informan A mengatakan alat dan fasilitas yang dibutuhkan adalah mixer, alat lem plastik, dan timbangan yang total biayanya sekitar Rp. 15.000.000,00. Sedangkan informan B mengatakan alat dan fasilitas yang dibutuhkan hanya yang umum saja seperti timbangan dan mixer. Informan A dan B mengatakan bahwa tidak ada biaya yang ditanggung apabila ada permintaan pelanggan yang tidak terpenuhi. Menurut Stevenson (2012:562), ada empat biaya pokok yang berhubungan dengan persediaan antara lain:

1. Biaya pembelian adalah jumlah yang dibayarkan kepada vendor atau supplier untuk membeli persediaan. Khusus biaya pembeliaan ini adalah persediaan terbesar diantara biaya yang lain.

2. Menahan, atau membawa, biayabiaya berhubungan dengan 
mempunyai barang fisik di gudang. Biaya-biaya tersebut termasuk bunga, asuransi, pajak (di beberapa negara), penyusutan, sesuatu yang sudah menjadi gaya lama dan tidak digunakan lagi, kerusakan, pembusukan, pencurian, kerusakan, pelacakan, pengambilan, dan biaya gudang (panas, lampu, sewa, keamanan). Biaya-biaya yang diikat tersebut memiliki peluang yang terkait dengan dana yang dapat digunakan di tempat lain dalam persediaan.

3. Biaya pemesanan adalah biaya dari pemesanan dan menerima persediaan barang.

4. Biaya kekurangan terjadi ketika permintaan melebihi pasokan persediaan yang ada di tangan. Biaya ini dapat terjadi karena tidak menghasilkan penjualan, kehilangan pelanggan yang baik, denda keterlambatan, biaya pemesanan ulang, dan biayabiaya yang sejenis lainnya.

Informan $\mathrm{C}$ mengatakan bahwa tidak ada biaya yang dikeluarkan apabila ada permintaan pelanggan yang tidak dapat terpenuhi karena jika pelanggan tidak membeli pun, dari pihak toko tidak mengeluarkan biaya apapun.

Volume Penjualan

Volume penjualan Toko Hokky Krian menurut Informan A dan B dalam sehari sekitar Rp. 15.000.000 hingga Rp. 20.000.000 terjadi peningkatan volume penjualan dari tahun ke tahun. Terjadi peningkatan volume penjualan dari tahun $2010 \mathrm{ke}$ tahun 2011 sebesar 7,95\%, sedangkan dari tahun 2011 ke tahun 2014 terjadi peningkatan sebesar $2,09 \%$.

Tabel 1 Total Pendapatan Toko Hokky Krian Tahun 2010, 2011, 2014 (dalam persen).

\begin{tabular}{|c|c|c|c|}
\hline Tahun & 2010 & 2011 & 2014 \\
\hline Persentase & $27,34 \%$ & $35,29 \%$ & $37,38 \%$ \\
Penjualan & & & \\
\hline
\end{tabular}

Sumber: Data Diolah (2015).

Pada penelitian terdahulu Nancy (2012:91), masalah kelebihan bahan baku yang terjadi bukan hanya kerena pembelian bahan baku yang tidak teratur, tetapi perusahaan dapat mengimbangi antara pembelian bahan baku dengan volume penjualan terjadi. Terdapat kendala meningkatkan 
volume penjualan di Toko Hokky

Krian pada saat pasar sepi menurut informan A dan B. Hal tersebut diatasi oleh informan $\mathrm{A}$ dan $\mathrm{B}$ dengan cara melakukan follow up kepada pelanggan. Informan B mengatakan dalam keadaan pasar sepi dapat mempunyai kesempatan untuk berkenalan dengan produkproduk baru. Menurut Rachmawati (2011:148) volume penjualan dapat dijabarkan sebagai umpan balik dari kegiatan pemasaran yang dilaksanakan oleh perusahaan.

Volume penjualan di Toko Hokky Krian pada tingkat tertinggi pada saat Hari Raya Idul Fitri, hal ini disampaikan oleh informan A dan B. Sedangkan pada penanggalan bulan Jawa yaitu bulan Suro merupakan volume penjualan Toko Hokky Krian dititik terendah. Pada saat titik terendah informan B melakukan diversifikasi produk dengan memperkenal produk baru atau produk yang kurang dikenal akan diperkenalkan lagi kepada pelanggan.

Informan A mengatakan dengan sistem inventory ini dapat meningkatkan volume penjualan karena dengan stock yang tertata lebih rapi dapat mempermudah dan mempercepat pembeli dalam berbelanja. Informan B mengatakan dengan sistem inventory ini dapat meningkatkan volume penjualan karena barang-barang tertata dengan rapi sehingga barang apa saja yang dipunyai dan stock barang apa saja yang ada dapat dengan mudah untuk ditawarkan kepada pelanggan. Informan $\mathrm{C}$ mengatakan bahwa dengan sistem inventory yang baik dapat membuat pelanggan mengharapkan produk yang akan dibeli pasti ada. Selain itu dengan adanya sistem inventory yang baik dan diimbangi dengan produk barang yang selalu baru maka semua orang akan datang dan volume akan meningkat. Dalam penelitian terdahulu yang dilakukan oleh Selvia (2014:v) mengatakan bahwa Economic Order Quantity (EOQ) dapat membantu perusahaan mengurangi adanya kesempatankesempatan yang terbuang akibat dari tidak adanya persediaan ketika pelanggan memesan.

Informan $\mathrm{C}$ mengatakan bahwa sistem inventory yang tepat untuk memaksimalkan volume penjualan adalah setiap hari melakukan 
pengecekan inventory, kalkulasi, dan tidak melakukan spekulasi. Sistem inventory yang paling tepat untuk Toko Hokky Krian menurut informan A dan B adalah sistem inventory yang sekarang sedang digunakan yaitu semua sistemnya menggunakan komputer begitupun juga untuk stock barang dan selain itu menggunakan barcode untuk setiap item yang ada. Jadi memudahkan untuk barangnya dapat ditata sesuai dengan jenis dan ragamnya, tetapi dengan seiring berjalannya waktu sistem inventory ini akan dikembangkan untuk menjadi lebih baik lagi.

\section{KESIMPULAN}

Kesimpulan dari penelitian ini adalah sistem inventory management yang baik dapat meningkatkan volume penjualan di Toko Hokky Krian.Maka dari itu, inventory harus dilakukan secara teratur dan biayabiaya yang dikeluarkan harus diperhitungkan baik biaya penyimpanan maupun biaya produksi. Hal ini didukung oleh Hansen dan Mowen (2012: 318) mengatakan inventory dapat mempengaruhi pendapatan operasional.
Semenjak berdirinya Toko Hokky Krian pada tahun 1999, sistem inventory baru diterapkan di Toko Hokky Krian sejak tiga tahun yang lalu tetapi untuk melakukan itu dibutuhkan sebuah proses sehingga untuk memulai sistem inventory ini menggunakan komputerisasi dilakukan sejak pertengahan tahun 2014. Sistem inventory ini diawali dengan pendataan stock dan jenis barang-barang yang ada di Toko Hokky Krian dengan menggunakan sistem komputerisasi serta membuat barcode untuk setiap itemnya yang digunakan untuk mempermudah dalam menngecek stock yang ada dan mengurangi kecerobohan pada sistem kasir saat pembeli melakukan pembayaran. Hal tersebut disampaikan oleh supervisor Toko Hokky Krian yaitu informan B. Menurut informan C, sistem inventory penting bagi suatu perusahaan dan dalam melaksanakannya jika mengggunakan sistem komputerisasi maka kesalahannya akan mencapai angka nol tetapi dibalik itu semua juga harus ada orang yang dapat menjalankan inventory ini dengan baik. Dalam melakukan inventory 
maka akan ada biaya-biaya yang harus ditanggung antara lain biaya mesin dan biaya penyimpanan. Menurut Stevenson (2012:562):

"Salah satu biaya dari empat pokok biaya adalah menahan, atau membawa, biaya-biaya berhubungan dengan mempunyai barang fisik di gudang. Biaya-biaya tersebut termasuk bunga, asuransi, pajak (di beberapa negara), penyusutan, sesuatu yang sudah menjadi gaya lama dan tidak digunakan lagi, kerusakan, pembusukan, pencurian, kerusakan, pelacakan, pengambilan, danbiaya gudang (panas, lampu, sewa, keamanan). Biaya-biaya yang diikat tersebut memiliki peluang yang terkait dengan dana yang dapat digunakan di tempat lain dalam persediaan.

Selain itu, dari sistem inventory management ini Toko Hokky Krian mendapatkan keuntungan potongan harga karena pembelian dengan jumlah yang cukup banyak untuk menyiapkan stock. Keuntungan lainnya adalah dapat menjual barang yang ada karena sistem inventor yang baik disaat proses produksi tidak dapat selesai pada waktu yang ditetapkan. Selain itu, dapat membentuk kepercayaan pelanggan kepada Toko
Hokky dengan selalu adanya barang yang diinginkan pelanggan dibutuhkan sistem inventory yang baik. Hal ini didukung dengan pernyataan dari ahli yaitu informan $\mathrm{C}$, bahwa dengan sistem inventory yang baik dapat membuat pelanggan mengharapkan produk yang akan dibeli pasti ada.

Selain itu, ada kendala dalam meningkatkan volume penjualan yaitu dimana saat keadaan pasar yang tidak selalu ramai karena disetiap penjualan ada musim tertentu pada saat volume penjualan paling tinggi dan ada juga disaat dimana penjualan pada titik terendah. Maka disitulah harus dilakukan upaya untuk meningkatkan volume penjualan saat titik terendah. Peran penting dari sistem inventory disini adalah dapat menunjukkan data bahwa pada tahun sebelumnya saat bulan-bulan tertentu akan mengalami volume penjualan dititik terendah sehingga dapat membantu untuk mengatur stock barang saat bulan tersebut, begitu pun sebaliknya saat volume penjualan tertinggi maka akan dapat memabantu untuk memutuskan jumlah stock yang akan dibeli sesuai dengan jenis barangnya. 
Oleh karena itu, informan $\mathrm{C}$ mengatakan melakukan inventory setiap hari, kalkulasi dan tidak melakukan spekulasi untuk dapat memaksimalkan volume penjualan.

Berdasarkan hasil, pembahasan, dan kesimpulan yang telah disusun, peneliti akan memberikan beberapa saran yang diharapkan dapat menjadi masukan bagi Toko Hokky Krian mengenai sistem inventory management untuk meningkatkan volume penjualan adalah sebagai berikut:

1. Jenis barang yang berjumlah ribuan pada Toko Hokky Krian yang biasanya dilakukan pengecekan selama satu seminggu sekali sebaikanya dapat dilakukan setiap hari agar dapat meminimalisir stock barang yang kosong sehingga dapat meningkatkan volume penjualan.

2. Dalam mempermudah melakukan inventory yang jumlah barangnya ribuan maka sebaikanya menggunakan analisis ABC (Activity Based Costing). Analisis $\mathrm{ABC}$ adalah sebuah aplikasi persediaan dari prinsip Pareto. Prinsip Pareto menyatakan "sedikit hal yang kritis dan banyak yang sepele". Gagasannya adalah untuk membuat kebijakan-kebijakan persediaan yang memfokuskan persediaan pada bagian-bagian persediaan kritis yang sedikit dan tidak pada banyak yang sepele. Tidaklah realistis jika memantau barang-barang yang tidak mahal dengan intensitas yang sama dengan barangbarang yang sangat mahal. Analisis $\mathrm{ABC}$ membagi persediaan yang ada menjadi tiga klasifikasi dengan basis volume dolar tahunan. Untuk menentukan volume dolar tahunan dari analisis $\mathrm{ABC}$, dilakukan dengan cara mengukur permintaan tahunan dari setiap barang persediaan dikalikan biaya per unitnya. Barang-barang kelas A adalah barang-barang yang volume tahunannya tinggi. Walaupun barang-barang ini mungkin hanya mempresentasikan 15\% dari barang-barang persediaan total, tetapi barang-barang tersebut merepresentasikan $70 \%$ sampai $\quad 80 \%$ dari 
penggunaan uang secara

keseluruhan. Barang-barang

Kelas B adalah barang persediaan dengan volume dolar tahunan yang sedang. Barang-barang ini mungkin merepresentasikan sekitar 30\% dari barang-barang persediaan dan $15 \%$ sampai $25 \%$ dari nilai total. Barang-barang dengan volume tahunan yang kecil adalah Kelas $\mathrm{C}$ yang mungkin hanya merepresentasikan $5 \%$ dari volume dolar tahunan, tetapi mewakili sekitar 55\% barang-barang persediaan total. Hal ini dikarenakan tidaklah realistis jika memantau barangbarang yang tidak mahal dengan intensitas yang sama dengan barang-barang yang sangat mahal.

3. Pengadaan pelayanan kontrol inventory dengan melakukan pemilihan, pelatihan, dan pendisiplinan pada pegawai yang dapat membantu dalam sistem inventory ini. Pegawai melakukan kontrol yang ketat dari pengiriman barang yang datang dan memastikan barang tersebut tersimpan dengan baik, yang dimaksud baik disini adalah barang tersebut terhindar dari bahaya binatang yang dapat merusak barang, suhu penyimpanan yang tepat untuk barang-barang tertentu, dan meletakkan barang sesuai dengan tanggal kadaluarsa sehingga barang tersebut yang harus dijual terlebih dahulu. Dalam melakukan produksi diperlukan pengontrolan pada semua bahan baku yang akan dibuat apakah bahan baku dalam keadaan yang baik untuk produksi serta pengontrolan yang ketat saat melakukan produksi sehingga produk yang dihasilkan maksimal.

4. Dapat melakukan kerjasama dengan bakery pada wilayah Sidoarjo atau Surabaya untuk dapat menjadi supplier tetap bagi bakery tersebut sehingga dengan adanya penjualan yang pasti dapat membantu meningkatkan volume penjualan Toko Hokky Krian. 


\section{DAFTAR PUSTAKA}

Actual.co. 2014. Kadin Prediksi Industri Roti dan Kue Meroket pada 2015.

http://www.aktual.co/ekonomibisnis/kadin-prediksi-industri-roti-dan kuemeroketpada-2015.

Ashok Kumar Panigrahi. 2013. Relationship Between Inventory Management and Profitability: An Empirical Analysis of Indian Cement Companies. Asia Pacific Journal of Marketing \& Management Review Vol. 2 (7), July (2013).

Business Dictionary. 2015. Sales Volume Definition. http://www.businessdictionary.com/definition/sales-volume.html.

Farah Margaretha. 2011. Manajemen Keuangan Untuk Manajer Nonkeuangan. Jakarta: Penerbit Airlangga.

Hansen, D. R.,dan Mowen M. M. 2013. Cornerstones of Cost Management.USA: South-Western, Cengage Learning.

Happy Ganadial Stephyna. 2011. Analisis Kinerja Manajemen Persediaan Pada PT. United Tractor. Fakultas Ekonomi Universitas Diponegoro. Semarang.

Haris Herdiansyah. 2010. Metode Penelitian Kualitatif. Jakarta: Penerbit Salemba Humanika. Heizer, J., \& Reinder, B. 2011.Operations Maagement.United State of America: Pearson. . 2010. Manajemen Operasi Buku 2 Edisi 9. Jakarta:

Salemba Empat.

Jacobs, F. R., \& Chase, R. B. 2013. Operations and Supply Chain Management: The Core. New York: McGraw-Hill.

Lexy J. Moleong. (2010). Metodologi Penelitian Kualitatif. Bandung: Remaja Rosdakarya.

Mangan,J., C. Lalwani, T. Butcher, and R. Javadpour . 2012. Global Logistics \& Supply Chain Management. United Kingdom : John Wiley \& Sons Ltd.

Maria Theodora Yuliana. 2013. Peningkatan Pelayanan Melalui Skill, Knowledge, dan Attitude Pramusaji di Kafe X Surabaya Barat. Tugas Akhir Universitas. Surabaya. 
Mowen, Hansen, and Heitger. 2012. Managerial Accounting The Cornerstone of Business Decisions. United States: South-Western, Cengage Learning.

Nana Syaodih Sukmadinata. 2010. Metode Penelitian Pendidikan. Bandung: PT Remaja Rosdakarya.

Olivia Philia Danudibrata. 2014. Analisis Pengendalian Persediaan Dengan Menggunakan Metode EOQ danJust In Time (Studi kasus: Joeragan). Tugas Akhir Universitas Ciputra. Surabaya.

Pardi Affandi, Faisal, dan Yuni Yulida. 2012. Penerapan Teori Kendali Pada Masalah Inventori. Jurnal Matematika Murni dan Terapan Vol.6 No.2 Desember 2012 : 38-46 Universitas Lambung Mangkurat. Banjarbaru.

Rina Rachamawati. 2011. Peranan Bauran Pemasaran (Marketing Mix) terhadap Peningkatan Penjualan (Sebuah Kajian terhadap Bisnis Restoran). Jurnal Kompetensi Teknik Vol. 2, No. 2. Jurusan Teknologi Jasa dan Produksi, FT, Universitas Negeri Semarang.

Selvia. 2014. Analisis Perbandingan Perencanaan Persediaan Menggunakan Metode Just In Time dan Economic Order Quantity Pada Perusahaan Milkyman di Surabaya

Stevenson, W. J. 2012.Operations Management eleventh edition. New York:McGraw-Hill Irwin.

Sugiyono, 2010 .Metode penelitian kuantitatif, kualitatif dan R\&D. Bandung : Alfabeta.

Tan Nancy. 2012. Analisis Pengendalian Persediaan Bahan Baku Pada Perusahaan Citra Exotic Surabaya. Tugas Akhir Universitas Ciputra. Surabaya.

Widya Lestari Putri. 2014. Manajemen Persediaan. Sekolah Tinggi Ilmu Ekonomi Yasa Anggana Garut.

Widya Tamodia. 2013. Evaluasi Penerapan Sistem Pengendalian Intern Untuk Persediaan Barang Dagang Pada PT. Laris Manis Utama Cabang Manado. Fakultas Ekonomin Jurusan Akuntansi Vol. 1, No. 3 Tahun 2013. Universitas Sam Ratulangi. Manado.

Yusnizal Firdaus. 2011. Peranan Biaya Promosi Dalam Meningkatkan Volume Penjualan Vol. 1 No. 2. Jurnal Ekonomi dan Informasi Akutansi Politeknik Negeri Sriwijaya Palembang. 